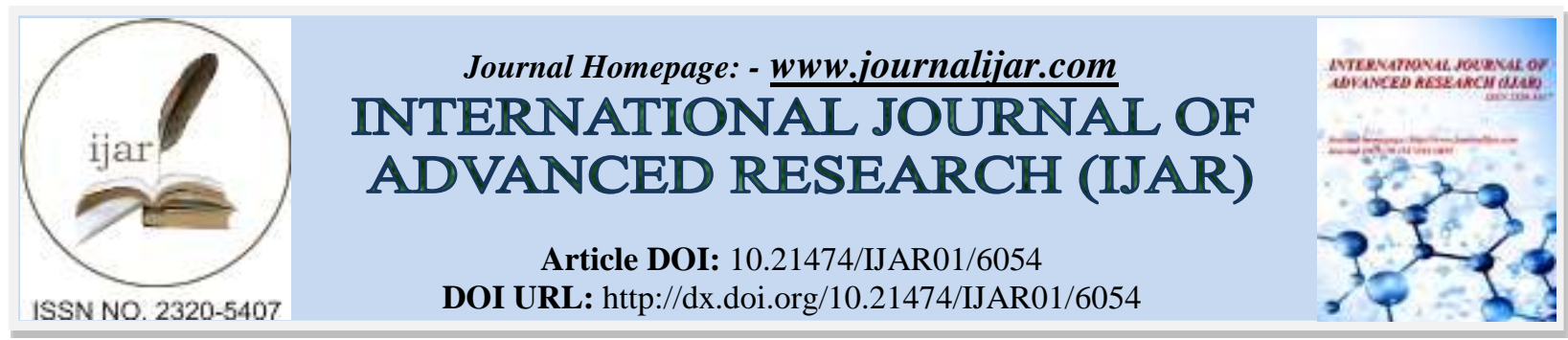

RESEARCH ARTICLE

\title{
LEADERSHIP STYLES AND WORK CULTURES: ITS EFFECT ON STAFFS' NEW ENVIRONMENTAL PARADIGM (NEP).
}

\section{Eko Suroyo, I Made Putrawan and Nadiroh.}

\section{Manuscript Info} [.......................... Manuscript History

Received: 14 October 2017

Final Accepted: 16 November 2017

Published: December 2017

Key words:-

New Environmental Paradigm, leadership styles, work culture.

\section{Abstract}

The objective of this research is to find out the effect of leadership styles and work culture on staffs NEP. Research method was ex post facto by $2 \times 2$ factorial design. Involving samples of this research was 60 staffs of Jakarta local district. Research results showed that (1) staffs NEP who have a transformational leadership style was different from the transactional one. (2) staffs NEP who has a strong work culture was different from the weak one. (3) For a strong work culture group, staffs NEP who has a transformational leadership style was higher than the transactional one. (4) For weak work culture groups, staffs NEP who has a transformational leadership style was lower than the transactional one. (5) There was an interaction effect between leadership styles and working cultures on staffs NEP. Thus it can be concluded that if someone wants to improve staffs NEP, it can be done by improving both leadership style and working culture.

Copy Right, IJAR, 2017,. All rights reserved.

\section{Introduction:-}

Nowadays, the environmental degradation have increased the awareness and public concern towards the environmental actions. The environmental awareness is expected to become a factor that influences the effort of environmental conservations. The survey results of Indonesian Environmental Agency about 'Indonesia's Environment Status in Public Opinion' stated that the environment conditions in Indonesia is in a dangerous state. Most of people in Indonesia proclaim that their environment is in danger. Meanwhile, many people argue that the law enforcement for the people who create environment devastations is minimum. These surveys are done in five different cities in January 2014: Jakarta, Bandung, Pekanbaru, Banjarmasin, and Kendari by using 1.920 respondents as samples. The environmental states that are analysed through the surveys consist of four aspects; the physical conditions of the environment and how to tackle it, the government institution capacities, the regional leaderships, and public participations. Most of the respondents stated that the groundwater condition in their area are relatively good, however it has smell, muddy and dirty. Despite of the worse environment conditions, most of the respondents stated that the capacities of the staffs in handling the environment are very low. This situation shown from the public views who stated that there is no remarkable works of the staffs to prosecute the people who harm the environment in to the court. These situations are also happened in Kepulauan Seribu District. The natural resources should make this region having a good prospective tourism and fishery, but in facts there are many people in this area who have low economic incomes. This gap shows that the staffs has not explored the marine resources maximaly to enhance the economic situation. Thus reveals that the staffs awareness in a form of the New Environmental Paradigm (NEP) has not been realized and applied. 
Dunlap and Van Liere as cited by Luzer, et. al., (2011: 1) stated that the implicitly NEP in the environment is a challenge for the basic view of every people toward the relationship of nature and human. As a result, the NEP is important for the staffs in using his position to manage his employees to be informed toward the environment awareness movement.

The low awareness of the staffs toward the NEP is caused by several factors. The staffs might not appropriately apply the leadership style. According to Fiedler, as cited by Robbins dan Judge (2009: 427), the key factor of a successful leadership is the basic individual leadeship style. However, Burns stated as cited by Pastor (2016: 1), that a transactional leader is a leader that exchange real reward for the job performances and loyality of his employees. Concurrently, a transformational leader is a leader that involved with his employees, focus into a higher intrinsic needs, and increase his awareness towards the importance of a specific matters. Beside a leadership style, the awareness attitude towards the environment in a form of the NEP is possibily created by work culture. Lingham (2014: 1) stated that a work cultureis a combination of organization's qualities and its employees that appeared from the opinion, as an appropriate ways to think and acts, but it need to be remembered that there are two working cultures, thus are a strong work culture and a weak work culture. Grodnitzky (2015: 1) stated that a work culture is weak when faith, behavioural rules, tradition, and the rites are not clear for the organization member or there are differences between the value statements and behaviours. On a contrary, a culture is considerably strong when there is cohesion between faith, behavioural rules, tradition, and the rites.

\section{Research Methodology:-}

This research aims to analyse the affect of leadership style and work culture into staffs NEP of Kepulauan Seribu District. This research is ex post facto of 60 samples by a Purposive Sampling technique. The research design used was $2 \times 2$ factorial design. Meanwhile, the inferensial analysis is used to tests the hypotheses by using two ways ANAVA. All of the hypotheses tests are done by using $\alpha=0,05$. Before the hypotheses tests are done, a normality test was performed first by using Lilliefors technique, and a homogenity test was performed by using Bartlett test.

\section{Research Findings and Discussion:-}

The test results of two groups and interaction using ANAVA test is as follows:

Table 1:- Two-Way ANOVA

\begin{tabular}{|c|c|c|c|c|c|c|}
\hline \multirow[t]{2}{*}{ Source of Variances } & \multirow[t]{2}{*}{ df } & \multirow[t]{2}{*}{ SS } & \multirow[t]{2}{*}{ MS } & \multirow[t]{2}{*}{$\mathbf{F}_{\text {cal }}$} & \multicolumn{2}{|c|}{$\mathbf{F}_{\text {table }}$} \\
\hline & & & & & .05 & .01 \\
\hline $\begin{array}{l}\text { Between group } \\
\text { Within group }\end{array}$ & $\begin{array}{c}3 \\
56 \\
\end{array}$ & $\begin{array}{l}1.946,448 \\
1.928,531 \\
\end{array}$ & $\begin{array}{r}648,815 \\
34,436 \\
\end{array}$ & $18,838 * *$ & 2,769 & 4,152 \\
\hline $\begin{array}{l}\text { Leadership style (A) } \\
\text { Work culture (B) } \\
\text { Int. (A) X (B) }\end{array}$ & $\begin{array}{l}1 \\
1 \\
1\end{array}$ & $\begin{array}{r}220,415 \\
236,015 \\
1.490,015\end{array}$ & $\begin{array}{r}220,415 \\
236,015 \\
1.490,015 \\
\end{array}$ & $\begin{array}{r}6,398 * \\
6,851 * \\
43,265 * *\end{array}$ & 4,004 & 7,058 \\
\hline Total & 59 & $3.874,979$ & & & & \\
\hline
\end{tabular}

$* \mathrm{p}<.05 ; * * \mathrm{p}<.01$

To test the first hypotheses which states that there is differences NEP between the staffs who have Transformational Leadership Style compared to transactional.

The calculation result shows that $F_{\text {cal }}=6,398$, meanwhile for $F_{\text {table }}$ at $\alpha=0,05\left(F_{\text {table }} 0,05\right)=4,004$. As a result, $F_{\text {cal }}>$ $\mathrm{F}_{\text {table, }}$ or 6,402 > 4,004, Ho is rejected and $\mathrm{H} 1_{\text {is }}$ accepted. This is based on the rejection criteria of $\mathrm{H}_{\mathrm{o}}$ : reject Ho if the price of $F_{\text {cal }}$ is greater than $F_{\text {table }}$ at significancy level of $\alpha=.05$. This is means that the hypothesis that is proposed by the researcher was accepted or there is a significant difference NEP between the staffs who has Transformational Leadership Style and the Transactional one.

To test the second hypothesis which stated that there is NEP differences between the staffs who have Strong and Weak Work Culture.

The calculation result shows that $\mathrm{F}_{\text {cal }}=6,851$ meanwhile for $\mathrm{F}_{\text {tabel }}$ at $\alpha=0,05\left(\mathrm{~F}_{\text {tabel }} 0,05\right)=4,004$. As a result, $\mathrm{F}_{\text {cal }}>$ $F_{\text {table }}$ or $6,385>4,004$, therefore $H_{o}$ is rejected and $H_{1}$ is accepted. This is based on the criteria of $\mathrm{H}_{0}$ rejection: reject Ho if the price of $F_{c a l}$ is greater than $F_{\text {table }}$ at significancy level of $\alpha=0.05$. This is means that the hypothesis 
proposed by the researcher is accepted, or there is a significant difference NEP between the staffs who have Strong and Low Work Culture.

To test the third hypothesis which is stated that for the Strong Work Culture, staffs NEP that have Transformational Leadership Style is higher than the Transactional one.

The calculation result using Tukey test shows that $\mathrm{Q}_{\text {cal }}=6,120$ while $\mathrm{Q}_{\text {table }}=3,860$. Based on the test criteria of $\mathrm{H}_{\mathrm{o}}$ rejection, if the value of $\mathrm{Q}_{\text {cal }}>\mathrm{Q}_{\text {table }}$ then $\mathrm{Ho}$ is rejected and $\mathrm{H}_{1}$ is accepted or accept the hypothesis proposed by the researcher. It can be concluded that for the Strong Work culture group, staffs NEP who have the Transformational Leadership Style is higher than the Transactional one.

\section{The Fourth Hypothesis:-}

The fourth hypothesis that tested in this research is for the Weak Work culture group. Staffs NEP who have Transformational Leadership Styles is lower that the Transactional one.

The calculation result using Tukey test shows that the value of $\mathrm{Q}_{\text {cal }}=-2,72$ meanwhile the value of $\mathrm{Q}_{\text {table }}=3,860$. Based on the criteria of the rejection test $\mathrm{H}_{\mathrm{o}}$, if the value of $\mathrm{Q}_{\text {cal }}<\mathrm{Q}_{\text {table }}$ then $\mathrm{H}_{\mathrm{o}}$ is rejected, and accepts $\mathrm{H}_{1}$ or accepts the hypothesis proposed by the researcher. It can be concluded that for the Weak Work culture group, staffs NEP who have the Transformational Leadership Style is lower than the Transactional one.

\section{The Fifth Hypothesis :-}

Tested in this research is: there is interaction between the Leadership style and the Work culture into the NEP. With the criteria of $\mathrm{H}_{\mathrm{o}}$ rejection: reject $\mathrm{H}_{\mathrm{o}}$ if the price of $\mathrm{F}_{\text {cal }}$ is higher than $\mathrm{F}_{\text {table }}$ at signification level $\alpha=0,05$. As a result $F_{\text {cal }}=43,265$ while for $F_{\text {table }}$ at $\alpha=0,05\left(F_{\text {table }} 0,05\right)=4,004$ as a result $F_{\text {cal }}>F_{\text {table }}$ or 43,265 4,004 so that $H_{o}$ is rejected and $\mathrm{H}_{1}$ is accepted. This is means that the hypothesis proposed by the researcher is accepted. It can be concluded that there is interaction between the Leadership Style and the Work cultureinto the NEP.

The first hypothesis result shows a significant result. Thus it can be interpreted that staffs NEP who have a transormational leadership style is different compared to the staffs that have a transactional leadership style. The research result also shows that staffs NEP that have transformational leadership is higher than the transactional one. As a conclusion, it can be interpreted that the staffs that have transformational leadership style shows a higher NEP compared to the staffs that have transactional leadership style.

The main principles of the NEP according to Catton dan Dunlap (2000: 41-49) are: (1) Despite humans having incredibles characteristics; (2) Human's situations are affected by the environment; (3) Humans live and depend on limited biophysic environment; (4) Many human's creations that altered the ecological carrying capacity law. Due to a different mindset among leaders, it is possible that the staffs that have different leadership styles also having a different NEP.

The research result describes staffs NEP that have Transformational leadership style is different compared to the transactional one, supports the theory described by James MacGregor Burns, as cited by Pastor (2016: 1), that there is a difference between the Transactional Leadership and the Transformational Leadership. A transactional leader is a leader who exchanges the real reward for works and loyalty of his employees. Concurently, a transformational leader is a leader who involves his employees, focus on a higher intrinsict need, and enhances awareness toward important specific matters. Burn stated a similar opinion, as cited by Campling et al. (2002: 372), the term of a transformational leader depicts a person who realy inspired as a leader and generates other to reach incredible work performances. Likewise, Goodwin, Wofford, and Whittington stated as cited by Bass et al. (2003: 208), there is a positive relation between transformational leadership and organizational behaviour that distinguish a transactional leadership which is more based on recognition that rely on expectations and basic purposes.

This research results confirm theories proposed by experts who stated that there are differences between the transformational and transactional leadership styles. Therefore, staffs NEP that have a transformational leadership style is different compared to the transactional one.

The second hypothesis test shows a significant result. Therefore, it can be depicted that staffs NEP that have strong work culture is different compared to the weak one. The research results also reveals that staffs NEP that have a 
strong work culture is higher than the staffs that have a weak work culture. The NEP is awareness toward the environment. According to Luzer, et. al. (2011: 1), the NEP proposed by Dunlap dan Van Liere (1978) is based on assumption that implicitly in an environment it is a challenge for the basic opinion of every human toward the relationship between humans and nature. Global Environments \& Societies (2011: 1) stated the NEP principles are follows: (1) human is a species that interdependence (2) the complexity of cause and effect, and feedback (3) the world is limited. As a result, it is reasonable that staffs NEP that have strong work culture will be different with the weak work culture. As it stated by Colquit, LePine, and Wesson (2009: 556), that the strong work culturehas a function to directly unites and integrates the employees. Grodnitzky (2015: 1) explained that a work cultureis weak when the faith, behavior rules, traditions, and it rites are not clear for the organization's member or there are difference between the value statements and behaviours. Meanwhile, in a strong work culture, the organization's member have faith, behavior rules, traditions, and rites in its public appearaances so that the employees can use the culture elements in decision making for all of the organization.

Byrne, as cited by Kumar (2016: 1) explains that a strong work culture will give bigger influences for the employees compared to a weak work culture. Hence, a strong work culturewill be a key of successful staffs in motivating environmental awareness in a form of NEP.

The research results support the theories that described by the experts that there is difference between a leader who has a strong and a weak work culture. Therefore, staffs NEP that have strong work cultureis different compared to the staffs that have weak work culture.

The third hypothesis shows a significant result. Therefore it can be concluded that for a strong work culture group, staffs NEP who have transformational leadership style is higher than the staffs that have transactional leadership style. Thus, according to the theory explained by Maseko (2017: 4) that it is interesting to propose strong work culture compare to weak work culture because it indirectly influences the employees intrinsict motivation, and by using reward as extrinsict motivator can make the employees embrace and identify the values and organization's norms. Thus is reasonable because the NEP is an environmental awareness. Accordingly, in a strong work culture it needs a transformational leadership style. Bass, as cited by Ivancevich, Konopaske, and Matteson (2008: 432) stated that there are three factors that explain the transformational leadership, name it: (1) Charisma (2) Individual attention (3) Intelectual stimulation.

For a strong work culture, staffs NEP who have the transformational leadership style is higher than the transactional leadership style. Burns, as cited by Pastor (2016: 1), stated that there are differences between the transactional leadership style and the transformational leadership style. This difference creates different opinions towards environment (NEP).

The research support the expert theories that for the strong work culture, staffs NEP that have transformational leadership style is higher than the transactional leadership style. The test of the fourth hypothesis shows a significant result. Thus it can be interpreted for the weak work culture; staffs NEP with transformational leadership style is lower than transactional one. This is in accordance with Riley's (2014: 2) opinion that a weak work culture may arise when the core values are not clearly defined, communicated or widely accepted by those working for the organization. For the weak work culture, a transactional leadership style is needed as stated by Surbhi (2015: 2) that a transactional leadership style uses reward and punishment to motivate the subordinates. It is include the effort of a leader to encourage the employees to aware toward the environment or the NEP. The employee's awareness toward environment or the NEP needs intrinsict encouragement from their leader. Dunlap and Van Liere as quoted by Luzar, et al. (2011: 1) stated that there are three items in assessing the conceptual domain of the NEP, as follows: the belief in the human ability to create problem with nature, the limits of growth, and the exact role of man against his nature. Accordingly, a leadership style needed for a weak work culture is the transactional leadership style, as cited by Pastor (2016: 1), stated that transactional leaders exchange real rewards for works and subordinate loyalty. This differences resulting a different point of view toward the environment (NEP).

The research results support the expert theories that for a weak work culture group, staffs NEP who have transformational leadership style is lower than the transactional leadership style. The result of the fifth hypothesis test shows the influence of a leadership style interaction and a work culture is proven significantly. Therefore, It can be interpreted that a leadership style and a work culture are related to each other in influencing staffs NEP. The 
results support the theory put forward by Schein (2004: 242) that in long-established companies, one can trace many of their assumptions to the beliefs and values of the original founders and leaders.

Similarly, the results of Tsai's study (20011:2) which states that culture in an organization is very important, plays a big role in whether it is a happy and healthy work environment. This is reasonable because the leadership style is the leader's behavior in directing his employees.

As stated by Campling, et al. (2002: 365) the style of leadership is the behavior shown by a leader. Similar opinion was expressed by Newstrom and Davis (2002: 167) that a leadership style indicates the explicit and implicit actions of leaders; thus can be seen by their employees.

A leadership style will influencing his subordinate's behaviour as it stated by Cunningham and Cordeiro (2003: 140141) that the leadership style will affects the behaviour of his subordinates mainly supporting the favorable style used. Therefore, a leadership style is important to generates the employees to concern about the environment in a form of the NEP. A Work cultureis a working phylosophy that is embraced by people in execute their works. Lingham (2014: 1) declared work culture is a combination of quality in an organization and it employees that emerged from the assumption as the right way of thinking and acting.

Therefore, the research results support the theories of experts that there is interaction style influence of a leadership style and a work culture into staffs NEP.

\section{Conclusion:-}

Based on the results of research and discussions above, it can be concluded as follows: Generally, NEP of the staffs that has a transformational leadership style is different from the transactional one.In general, staffs NEP that has a strong work culture is different from the weak one.For a strong work culture group, NEP of the staffs that has a transformational leadership style is higher than the transactional one.For a weak work culture group, staffs NEP that has a transformational leadership style is lower than the transactional one. There is an interaction effect between leadership styles and working cultures on staffs NEP.

Therefore if staffs NEP could be increased, leadership styles was not strong enough, since interaction was highly significant, the role of work culture could not be neglected.

\section{References:-}

1. Bass, Bernard M. et al. "Predicting Unit Performance by Assessing Transformational and Transactional Leadership." Journal of Applied Psychology Copyright 2003 by the American Psychological Association, Inc. 2003, Vol. 88, No. 2.

2. Campling, John, et al. Management. New York: John Wiley \& Sons Australia, Ltd, 2002.

3. Catton, W. and R. Dunlap. "Environmental Sosiology: A New Paradigm" . Journal of The American Sosiologist 13. Washington State University, 2000.

4. Colquitt, Jason A., Jeffery A. LePine and Michael J. Wesson. Organizational Behavior: Improving Performance and Commitment in the Workplace. New York: McGraw Hill-Irwin, 2009.

5. Cunningham, William G. and Paula A. Cordeiro. Educational Leadership. New York: Pearson Education, Inc., 2003.

6. Global Environments \& Societies. New Environmental. http://enva320. wikispaces.com/ 4 December 2011.

7. Gustavo, Grodnitzky. Cuture Weak vs. Strong. http://study.com/academy/ 22 September 2015.

8. Ivancevich, John M., Robert Konopaske, and Michael T. Matteson. Organizational Behavior and Management. New York: McGraw-Hill, 2008.

9. Kumar, Dileep. Strong and Weak Organisational Culture and Behavioral Implications. https://www.linkedin.com/pulse/ 9 June 2016.

10. Lingham, Leo. Work Culture - Removing Stress. http://www.citehr.com 16 September 2014.

11. Luzar, E. Jane, et al. Evaluating Nature-based Tourism Using The New Environment Paradigm. J. Agr and Applied Econ (27) 2. http://ageconsearchumn.edu/ 4 December 2011.

12. Maseko, Thokozani S. B. "Strong vs. Weak Organizational Culture: Assessing the Impact on Employee Motivation," Arabian Journal of Business and Management Review , 2017, 7:1 DOI: 10.4172/22235833.1000287. 
13. Mullins, Laurie J. Management and Organization Behavior. Edinburgh, Harlow, Essex: Prentice Hall, 2005.

14. Newstrom, John W. and Keith Davis. Organizational Behavior. New York: McGraw Hill, 2002.

15. Pastor, Juan-Carlos. Transformational or transactional leadership? Is one better than the other? http://aiesec.or.id/ Diakses 16 September 2016.

16. Riley, Jim. Organisational Culture: Strong $v$ Weak https://www. tutor 2u.net/business/ 1 October 2014.

17. Schein, Edgar H. Organizational Culture and Leadership, Third Edition. San Francisco: John Wiley \& Sons, Inc., 2004.

18. Schermerhorn, John R. Jr., et al.,Organizations Behavior. New Jersey: John Wiley \& Sons, 2011.

19. Surbhi, S. Difference Between Transactional and Transformational Leadership. http://keydifferences.com/ 21 July 2015.

20. Tsai, Yafang. "Relationship between Organizational Culture, Leadership Behavior and Job Satisfaction." BMC Health Services Research doi: 10.1186/1472-6963-11-98 PMCID: PMC3123547, 2011. 